\title{
Does Corporate Capital Structure Influence Corporate Financial Performance in Developing Economies? Evidence from East African Stock Markets
}

\author{
Erick Lusekelo Mwambuli \\ School of Accountancy, Dongbei University of Finance and Economics, Dalian, China \\ $\&$ \\ Faculty of Accounting, Banking and Finance, Institute of Finance Management \\ Dar Es Salaam, Tanzania \\ E-mail: erickmwambuli@gmail.com
}

Received: April 22, 2016

doi: $10.5296 /$ ifb.v3i1.9357
Accepted: May 4, $2016 \quad$ Published: May 10, 2016

URL: http://dx.doi.org/10.5296/ifb.v3i1.9357

\begin{abstract}
This paper examines the statistically significant influence which capital structure has had on corporate financial performance of listed non-financial companies in East African stock markets. It used panel data of 272 observations including 34 East African non-financial listed firms listed in East African stock markets such as Dar Es Salaam Stock Market (DSE), Nairobi Securities Exchange (NSE) and Uganda Securities Exchange (USE) for a period of 8 years (i.e., 2006-2013). Using the Panel Corrected Standard Errors (PCSEs) and Fixed Effect (FE), the study formulated two econometric models with return on assets (ROA) and return on equity (ROE) as dependent variables and measures of corporate financial performance respectively, three independent variables such as short term debt ratio (STDR), long term debt ratio (LTDR) and total debt ratio (TDR) as a measure of capital structure, furthermore the study used size of the firm (SIZ) as a control variable in order to control the differences in firm's operating environment. The result indicates that capital structure has a negative and statistically significant influence on East African listed firm's financial performance at 5\% significance level. These results show that in average profitable listed firms in East African prefers to use internal source of financing in their capital structure as compared to external source of financing (like Debts-STDR, LTDR and TDR) and this results are supporting pecking order theory. Lastly the study recommends to corporate financial managers of East
\end{abstract}


African non-financial listed firms should reduce financing their operations and growth by debt (STDR, LTDR and TDR) on their capital structure in order to enhance their corporate financial performance, regulatory authorities in East African region such as East African member states securities regulatory authority (EASRA) to formulate policies that will improving of financial markets in the region in order to reduce the cost of debt, further research could examine the influence (if any) of capital structure on sector wise (as per industry-like Manufacturing firms) for East African non-financial listed firms, take into account more control variables which are likely to influence financial performance such as macroeconomic variables (like gross domestic product-GDP) and consider other capital structure theories like, market timing theory, agency theory which were not considered in our study.

Keywords: Capital structure, Corporate financial performance, Panel data, Developing economies, East African stock markets 


\section{Introduction}

Capital structure theory and its influence with a corporate performance and value has been a researchable and puzzling issue in finance literature. In general speaking, capital structure is a combination of debt and equity used to finance corporate operations and growth. Capital structure is a pure financing decision of a firm, therefore financial managers must take cautions on deciding the mix of debts and equity on the firm capital structure (Mwambuli, 2015). Financing decisions result in a given capital structure and sub-optimal financing decisions can lead to a corporate failure (Mwangi et al., 2014), hence to understand the relationship (if any) between capital structure and corporate financial performance it's very important. The relationship between capital structure and corporate Financial performance can be traced back since the seminal work about capital structure (Paper on the Irrelevance of Capital Structure) issued by Modigliani \& Miller (MM theory) published on 1958, on their paper they argue that under very restrictive assumptions of perfect capital markets (i.e., no taxes, no transactions cost, no agency cost, no bankruptcy cost, absence of information asymmetry, equivalence in borrowing cost for both companies and investors, bond and stock trades in perfect market, no effect of debt on company's earnings before interest and taxes) capital structure is irrelevant in determining firm value. According to MM theory, the company value is determined by optimal investments (its real assets) and not by the mix of securities it issues (capital structure). However, these restrictive assumptions do not hold in the real world, which led many scholars to introduce additional rationalization for this proposition and its underlying assumptions showing that capital structure affects firm value and its performance (Ebaid, 2009). However, up to now scholars are not speaking the same language regarding the relationship between capital structure and corporate financial performance, because the results from their empirical investigations are still contradictory and mixed. Some researchers documented a positive relationship between capital structure and corporate financial performance, other researchers documented a negative relationship between capital structure and corporate financial performance and other researchers documented that there is no any relationship between capital structure and corporate financial performance. Hence the relationship between capital structure and corporate financial performance is still a puzzle.

The aim of this paper is to explore the relationship between capital structure and corporate financial performance in East African Stock Markets Context, the study is very important because in many corporate finance literatures regarding the relationship between capital structure and corporate financial performance, many scholars were considering developed economies, but there are still few literatures which focused on developing economies, despite the few literatures on developing economies, but still scholars ignored the East African Stock Markets Context, to the best of my knowledge there is no any empirical study about the relationship between capital structure and corporate financial performance for East African region context and this paper is the first to consider the relationship between capital structure and corporate financial performance in the East African Stock Markets Context, the paper consider this East Africa region due to the several reasons (1) To fill the gap in existing finance literatures relating to capital structure and corporate financial performance because 
there no any empirical research as up to date on East African Stock Market while East African region is recently experiencing a rapid stock market developments (2) To help corporate financial managers of firms operating in East African region to make appropriate capital structure decisions, as accordance and appropriate to their operating region in order to maximize the value of their firm and enhance shareholders wealth (3) To help Securities markets regulatory authorities in East African region such as East African member states securities regulatory authority (EASRA) to formulate policies relating to securities markets (4) To provide a platform for future research in capital structure decisions and corporate financial performance especially for East African region and developing economies in general.

The rest of this paper is organized as follows: Section 2 presents relevant literatures review and research hypotheses, Section 3 is about research methodology, Section 4 presents results and discussion and finally Section 5 concludes the paper and give out recommendations.

\section{Relevant Literatures Review and Research Hypotheses}

\subsection{Capital Structure Theories}

Capital structure theories are explaining on how the firm choose between debt and equity as financing decision is concerned (Mwambuli, 2015). According to Myers (2003) there is no universal theory of capital structure and no reason to expect one and all capital structure models are conditional. Capital structure theories includes theories such as Modigliani and Miller (MM) theory, trade-off theory, pecking order theory, agency theory, market timing theory etc, but this study will limit its discussion on the most three dominant theories such as Modigliani Miller (MM) theory, Trade off theory and Pecking order theory, there are several reasons for limiting our discussions to these theories (1) Modigliani Miller theory is the first and original source of all other capital structure theories (2) Prior Literatures have been using cross-sectional tests and variables that can justified by using either trade off theory or pecking order theory (Huang \& Song, 2006; Khan et al., 2014)

\subsubsection{Modigliani and Miller Theory (MM Theory)}

Franco Modigliani and Merton Miller (MM theory) issued their seminal paper on 1958, asserts the firm value is not influenced by capital structure choices, the theory was based under very restrictive perfect market assumptions (i.e., no taxes, no transactions cost, no agency cost, no bankruptcy cost, absence of information asymmetry, equivalence in borrowing cost for both companies and investors, bond and stock trades in perfect market, no effect of debt on company's earnings before interest and taxes). As per MM theory, the company value is only determined by optimal investments (real assets) (Modigliani \& Miller, 1958/1961; Focardi \& Fabozzi, 2004; Igbinosa \& Chijuka, 2014; Mwambuli, 2015). However, in a real life situation those assumptions are not realistic, then after Modigliani \& Miller (1963) considered the effect of taxes and recommended firms to use as much debt as possible due to tax benefits because interest expenses is tax deductible, hence they concluded that the levered firm (geared firm/firm with debt) will have a high value as compared to unlevered firm (ungeared firm/firm without debt) due to amount of taxes saved by levered firm. 


\subsubsection{Trade-Off Theory}

According to Kraus \& Litzenberger (1973), there are benefits and costs when using debt to finance the company (See Kant, 2014), hence a firm will be financed partly with debt and partly with equity, the generally idea under trade off theory is about optimal capital structure and that a value maximizing firm will achieve this optimal capital structure by balancing the appropriate portion of debt and equity. According to trade off theory, the benefits of debts to a firm includes tax shield benefits while cost of debts to a firm includes agency cost and cost of financial distress to a firm, like bankruptcy cost. Ideally a firm will keep borrowing because of tax advantages the firm is getting from debts, and this will goes up to a point where tax advantages from tax shield benefit will be equally to financial distress cost, this means always the managers of the firms will struggle to trades off between the two extremes (i.e., debt benefits and debt costs), According to Myers (1984), the underlying principle of trade off theory is existence of target leverage and deviation from target could be eliminated via adjustment (Oke \& Obalade, 2015; Mwambuli, 2015).

\subsubsection{Pecking Order Theory}

The idea under the pecking order theory is asymmetric information concept, the theory point out that due to asymmetric information between the two sides (i.e., Managers and Investors) regarding the firm investment opportunities, then the market may undervalue the firm new shares relative to the value that would be revealed to the market. Hence, issuing new shares may harm existing shareholders through value transfer from old to new shareholders (Ebaid, 2009). The theory argued that, in order to finance the company managers applied the hierarchy of financing by starting with internal funds such as retained earnings to external financing where debts will be preferred first and equity will be the last resort of financing. Pecking order theory was first argued with Donaldson (1961) and later Myers \& Majluf (1984) modified the theory, as according to Myres (1984) internal sources of financing have a lower level of information asymmetry cost and seem to be safety, for that case will be given first order then after utilization of internal source, then debt (borrowing) will be the second order, lastly to externally equity (new issue of shares) and this will be the last due to the highest cost of information asymmetry. According to this theory there is no targeted debt ratio (optimal capital structure) but managers are just observing the order of financing as capital structure decision is concerned Mwambuli (2015).

\subsection{Empirical Evidences Relating to the Relationship between Capital Structure and Corporate Financial Performance}

The influence of capital structure on corporate financial performance is still a researchable topic in finance literature especially in developing economies, the empirical studies from prior researches come up with contradictory results. Therefore, up to date the disagreement exists not only in the theoretical literature but also on empirical studies.

2.2.1 A Significant Positive Relationship between Capital Structure and Corporate Financial Performance

A number of prior studies provide empirical evidence supporting a positive relationship 
between capital structure and corporate financial performances like Nirajini \& Priya (2013), Abu Rub (2012), San \& Hang (2011), Margaritis \& Psillaki (2010), Frank \& Goyal (2003), Holz (2002), Hadlock \& James (2002), Ghosh et al. (2000), Champion (1999), Roden \& Lewellen (1995), Petersen \& Rajan (1994), Givoly et al. (1992); Malanic et al. (2013). As for this positive relationship, these studies concludes that profitable firms (either firms with higher financial performance) will tend to have a large portion of debt finance in their capital structure, there are several reasons behind this situation. (1) it's because profitable firms will have higher taxable income and hence higher amount of tax savings from interest tax shields, so these firms will prefer to borrow as much as possible so as to benefit from this tax advantages. (2) In mostly cases lenders prefers to lend money (Loan/debt finance) to profitable firms because profitability is one of key good indicator for future good performances of a firm, hence lenders are willing to offer them money (Loan/debt finance) because these profitable firms gives an assurance of loan/debt finance repayment., so these firm will prefer to borrow as much as possible to take this advantage. This positive relationship between capital structure and corporate financial performance is supporting trade-off theory of capital structure.

\subsubsection{A Significant Negative Relationship between Capital Structure and Corporate Financial} Performance

Several empirical studies provide evidence of a negative relationship between capital structure and corporate financial performance like Kaumbuthu (2011), Karadeniz et al. (2009), Zeitun \& Tian (2007), Rao et al. (2007), Huang \& Sang (2006), Goddard et al. (2005), Ngobo \& Capiez (2004), Eriotis et al. (2002), Fama \& French (2002), Gleason et al. (2000) Simerly \& Li (2000), Majumdar \& Chhibber (1999), Crnigol \& Mramor (2009), Klapper \& Tzioumis (2008), Dragota \& Smenescu (2008), Song (2005), Chen (2004), Bauer (2004), Hall et al. (2004), Deesomsak et al. (2004), Cassar \& Holmes (2003), Esperanca et al. (2003), Nivorozhkin (2002), Shyam-Sunder \& Myers (1999), Friend \& Lang (1988), Malanic et al. (2013). As for this negative relationship, these studies gives the evidence that profitable firms will have higher amount of earnings, hence higher amount retaining earnings after the end of the financial year and this will automatically boost their internal source of financing, therefore these kind of firms will prefer to finance their operations and growth through internal financing (retained earnings) because it's very cheap as compared to external source of financing like Loan/debt finance, hence these profitable firms will have a small portion of debts in their capital structure. This negative relationship between capital structure and corporate financial performance is supporting pecking order theory of capital structure.

\subsubsection{A Weak (No any) Relationship between Capital Structure and Corporate Financial} Performance

A weak to no any relationship between capital structure and corporate financial performance was concluded by a number of empirical studies like Ebaid (2009), Baum et al. (2007), Phillips \& Sipahioglu (2004). As for this weak to no any relationship between capital structure and corporate financial performance, these studies gives the evidence that, the financial performance of the firm is not influenced by the capital structure of the firm but is 
influenced by its optimal investments (real assets). This weak to no any relationship between capital structure and corporate financial performance is supporting Modigliani \& Miller (MM) theory of capital structure.

\subsection{Research Hypotheses}

This study formulated the following hypotheses after considering prior literatures, for the purpose of investigating the relationship (if any) between capital structure and corporate financial performance.

H1: There is a positive relationship between ROA and capital structure.

$\mathrm{H} 2$ : There is a positive relationship between ROE and capital structure.

\section{Research Methodology}

\subsection{Scope, Population and Sample Size}

This study uses all publicly listed firms on East African Stock Exchanges during the period of 2006-2013. East African region comprises of five countries such as Tanzania, Kenya, Uganda, Rwanda and Burundi. This study excluded Rwanda and Burundi, because in Rwanda there is only one principal stock market (Rwanda Stock Exchange (RSE)) that was incorporated on 7th October 2005 and for this reason the financial data from RSE will not fulfill the requirements of the study time frame (i.e., eight years) and also we excluded Burundi because up to now (As at April, 2016), there is no any stock market in Burundi. Therefore, the population for this study will includes three countries only such as Tanzania, Kenya and Uganda and using financial data for firms listed in Dar Es Salaam Stock Exchange (DSE) in Tanzania, Nairobi Securities Exchange (NSE) in Kenya and Uganda Securities Exchange (USE) in Uganda, for the whole study period of eight years, (from 2006-2013).

The listed companies were then screened from the three stock markets (DSE, NSE and USE) against several factors such as (1) All financial institutions, including all banks and insurance companies listed in East African Stock Markets were excluded from the study, because the capital structure of these financial institutions is highly regulated by central banks and respective insurance regulatory authorities, Moreover, cash is trading assets of bank and hence the levels of cash holding are expected to be significant higher than for firms in other sectors (Mwangi et al., 2014). (2) The mining listed companies were also excluded from the study due to their big different in capital structure and nature of operations as compared to other listed companies (Mwambuli, 2015). (3) All newly listed firms and delisted firms during the period of this study were also excluded so as to remove any anomalies (Mwambuli, 2015). (4) Lastly the study eliminated some listed East African companies due to unavailability of data. Finally our sample size consisted of 34 non-financial listed firms.

\subsection{Data Sources}

The study used secondary data which was extracted from various sources, the main source was OSIRIS database and supplemented with East African Stock Market websites (DSE, NSE and USE) and firms websites (including firm annual reports) for the period under 
consideration (2006-2013), the study also consisted a critical review of academic literature from financial journals, books and articles to form a foundation of the study.

\subsection{Data Analysis}

Descriptive and inferential statistics were used in data processing. Descriptive statistics of variables were calculated for the whole period of study (from 2006-2013), then correlation analysis was employed to measure the extent of relationship among variables used in this study and panel multiple regression models to identify the most significant and influential independent variables on dependent variable. The panel methodology was done by using E-VIEWS 8 and STATA 10 statistical packages and this panel dataset comprises of 272 observations.

\subsection{Financial Performance and Capital Structure Variables Measurement (Proxy) and References}

The study uses two dependent variables, three independent variables and one control variable on analyzing if Capital structure influence corporate financial performance on East African Stock Market context, the study used book values for all of these variables in calculations due to the fact that this study is based on Annual reports of firms (i.e., financial statements) (See also Khan et al., 2014; Mwambuli, 2015).

\subsubsection{Dependent Variables}

This study uses two dependent variables as measures of corporate financial performance such as Return on assets (ROA) and Return on Equity (ROE).The study uses these two common accounting measure of financial performance because of several reasons, (1) East African Stock Markets as among of developing economies their capital markets are relatively under developed and are not active so accounting measures of financial performance are appropriate to measure firms performance as compared to market measures of financial performance (2) To make our results significant and comparable with prior studies, because these accounting measures of financial performance were mostly employed in previous empirical studies. The measurements of dependent variables and respective references are shown here below

Return on Assets $(R O A)=$ Net Profit $/$ Total Assets

(Alam et al. (2014), Pouraghajan et al. (2012), Zeitun \& Tian (2007))

Return on Equity $(R O E)=$ Net Profit / Total Equity

(Chang et al. (2014), Soumadi \& Hayajneh (2012), Onaolapo \& Kajoka (2010))

\subsubsection{Independent Variables}

The independent variables used in this study as a measure of capital structure were Short term debt ratio (STDR), Long term debt ratio (LTDR) and Total debt ratio (TDR). This study uses these three independent variables because East African Stock Market are not highly developed and active in term of capital markets, therefore many firms are depending on short term finances (Like Bank borrowings) as compared to long term finances (like Corporate 
bonds) so in order to figure out the influence (if any) of capital structure on corporate financial performance the study separates debts into two parts, short term debts and long term debts. The measurements of independent variables and respective references are shown here below.

Short term debt ratio $(S T D R)=$ Current liabilities / Total Assets

(Mwambuli (2015), Vinasithamby (2014), Bevan \& Danbolt (2002))

Long term debt ratio $($ LTDR $)=$ Non-Current liabilities / Total Assets

(Mwambuli (2015), Vinasithamby (2014), Michaelas (1999))

Total debt ratio $(T D R)=$ Total liabilities $/$ Total Assets

(Mwambuli (2015), Bevan \& Danbolt (2002), Michaelas (1999))

\subsubsection{Control Variable}

This study used size of the firm (SIZ) as a control variable in order to control the differences in firm's operating environment, the reason behind this control variable is because prior literatures suggest that firm size is likely to influence its financial performance, that larger firms have a greater variety of capabilities and can enjoy economies of scale which may affect the results and inferences (See Ramaswamy (2001), Frank \& Goyal (2003), Jermias (2008), Ebaid (2009)).

Size $(S I Z)=$ Natural logarithm of total assets

(Smith et al., (2012), Dewalheyns \& Van Hule (2012), Ebaid (2009))

\subsection{Model Specification}

This study tested the relationship between capital structure and corporate financial performance of firms in East African Stock Markets by the following regression models.

Model 1-Return on Assets (ROA)
a. $\quad$ ROAit $=\beta 0+\beta 1 \mathrm{STDR} i t+\beta 2 \mathrm{SIZit}+\varepsilon i t$
b. $\quad$ ROAit $=\beta 0+\beta 1$ LTDRit $+\beta 2$ SIZit $+\varepsilon i t$
c. $\mathrm{ROAit}=\beta 0+\beta 1 \mathrm{TDR} i t+\beta 2 \mathrm{SIZit}+\varepsilon i t$

Model 2-Return on Equity (ROE)
a. $\quad$ ROEit $=\beta 0+\beta 1$ STDRit $+\beta 2$ SIZit $+\varepsilon i t$
b. $\quad$ ROEit $=\beta 0+\beta 1$ LTDRit $+\beta 2$ SIZit $+\varepsilon i t$
c. $\mathrm{ROE} i t=\beta 0+\beta 1 \mathrm{TDR} i t+\beta 2 \mathrm{SIZit}+\varepsilon i t$

Where:

ROAit $=$ Return on assets of firm $\mathrm{i}$ at time $\mathrm{t}$ 
ROEit= Return on Equity of firm $\mathrm{i}$ at time $\mathrm{t}$

STDRit $=$ Short term debt ratio of firm $\mathrm{i}$ at time $\mathrm{t}$

LTDR $i t=$ Long term debt ratio of firm $\mathrm{i}$ at time $\mathrm{t}$

TDRit $=$ Total debt ratio of firm $\mathrm{i}$ at time $\mathrm{t}$

SIZit $=$ Size of firm $\mathrm{i}$ at time $\mathrm{t}$

$\beta 0=$ Intercept coefficient

$\beta 1-\beta 2=$ Coefficients of the concerned independent variables

$\varepsilon i t=$ Error term of firm $\mathrm{i}$ at time $\mathrm{t}$

\section{Result and Discussion}

\subsection{Descriptive Statistics}

Table 1 below, presents a summary of descriptive statistics of the independent and dependent variables used in this paper. As According to the Table, the descriptive parameters of sample companies in East African region can be analyzed into three aspects, first for dependent variables and secondly for independent variables and thirdly for a control variable. (1) The mean for dependent variables are, $1 \%$ and $7 \%$ for ROA and ROE respectively, from this figures of mean values we can comment on two issues, firstly it's a good news that all mean values for ROA and ROE have got positive values but secondly in general speaking, it shows sample firms in East African Stock Markets during 2006-2013 have got a poor performance (2) The mean for independent variables shows the mean total debt ratio (TDR) of $60 \%$, this mean that, in average the firms in East African region are operating with high level of financial leverage, because $60 \%$ of firms total assets are financed by debt and the rest $40 \%$ is equity financing, however out of $60 \%$ (total debt ratio), the mean long term debt ratio (LTDR) is $23 \%$ and the mean short term debt ratio (STDR) is $37 \%$, this suggest that, the corporate debt structure of East African region listed companies depend on short term liabilities (like bank borrowings etc.) for financing their operation more largely than long term liabilities (like corporate bonds etc.), this could be a results of less developed capital markets in East African region. (3) The mean for a control variable (i.e., Size of the firm (SIZ)) as measured as natural logarithm of total assets is 20, this suggest that East African firms are large firms in average as measured in terms of total assets..

Table 1. The descriptive statistics

\begin{tabular}{|l|l|l|l|l|l|l|}
\hline & ROA & ROE & STDR & LTDR & TDR & SIZ \\
\hline Mean & 0.010788 & 0.072800 & 0.370776 & 0.233276 & 0.604052 & 20.09995 \\
\hline Median & 0.006875 & 0.014608 & 0.391567 & 0.199062 & 0.659762 & 20.02867 \\
\hline Maximum & 0.066475 & 0.354946 & 0.548312 & 0.427796 & 0.812718 & 20.70464 \\
\hline Minimum & -0.061565 & -0.099747 & 0.193180 & 0.120151 & 0.313330 & 19.67238 \\
\hline Std. Dev. & 0.036778 & 0.138957 & 0.125800 & 0.096971 & 0.196391 & 0.330524 \\
\hline Observations & 272 & 272 & 272 & 272 & 272 & 272 \\
\hline
\end{tabular}

Source: E-Views 8 analysis of data 


\subsection{Preliminary Analysis}

\subsubsection{Testing for Multicollinearity (Correlation Analysis)}

Table 2 below, the results of Pearson correlation matrix of independent variables and control variable used in this study are presented, According to the pair-wise correlation coefficient on Table 2 below, the results suggest that there is no multicollinearity problem between independent variable and control variable used in this study for sample companies of East African stock market. There will be a multicollinearity problem if the correlation coefficient between any two independent variables in a sample is +/- 0.80 or higher (Lewis-Beck, 1993; Hossain \& Hossain., 2015; Mwambuli, 2015). As per Table 2 below the lowest correlation coefficient is +0.032966 between short term debt ratio (STDR) and size of the firm (SIZ) which suggest a very weak positive correlation between the two independent variables while the highest correlation coefficient is +0.529714 between long term debt ratio (LTDR) and size of the firm (SIZ) and this suggest an average positive correlation between the two independent variables.

Table 2. The pearson correlation matrix

Source: E-Views 8 analysis of data

\begin{tabular}{|l|l|}
\hline & SIZ \\
\hline SIZ & 1.000000 \\
\hline STDR & 0.032966 \\
\hline LTDR & 0.529714 \\
\hline TDR & 0.282671 \\
\hline
\end{tabular}

\subsubsection{Unit Root Test}

A data series is supposed to be stationary in order for an econometric model to report appropriate results relating to the relationship between dependent variable and independent variables. A data series which does not have a constant mean, variance and auto-covariance at various lags over time is known as non-stationary (Gujarati, 2007; Hossain \& Hossain, 2015; Mwambuli, 2015). Therefore, to test for unit root of the data series in this study, we use Levin-Lin- Chu (LLC) test because it's appropriate for strongly balanced panel dataset data and our dataset satisfy this requirement. The following hypothesis is considered for this test.

Null hypothesis (Ho): Panel data contains unit root [non-stationary].

Alternative hypothesis (H1): Panel data is stationary.

The LLC test results on Table 3 below, shows that all variables used in our econometric models are stationary at both individual intercept and individual intercept and trend. These variables are said to be stationary due to the fact our p-value is significant at 5\% significance level, therefore, the study rejected the null hypothesis and accept the alternative hypothesis that our panel dataset is stationary. 
Table 3. The unit root test results-Levin, Lin \& Chu (LLC) test

\begin{tabular}{|c|c|c|c|c|c|c|}
\hline \multicolumn{7}{|c|}{ Null: Unit root (assumes common unit root process) } \\
\hline \multicolumn{3}{|c|}{ With individual intercept } & \multicolumn{4}{|c|}{ With individual intercept and trend } \\
\hline Variable & t-statistic & Probability & Process & t-statistics & Probability & Process \\
\hline ROA & -4.38750 & 0.0000 & Stationary & -17.9877 & 0.0000 & Stationary \\
\hline ROE & -7.7589 & 0.0000 & Stationary & -16.8306 & 0.0000 & Stationary \\
\hline STDR & -8.00016 & 0.0000 & Stationary & -128.964 & 0.0000 & Stationary \\
\hline LTDR & -17.5397 & 0.0000 & Stationary & -12.1259 & 0.0000 & Stationary \\
\hline TDR & -11.1349 & 0.0000 & Stationary & -30.7561 & 0.0000 & Stationary \\
\hline SIZ & -10.4828 & 0.0448 & Stationary & -11.6439 & 0.0000 & Stationary \\
\hline
\end{tabular}

Source: E-VIEWS 8 analysis of data

\subsubsection{Hausman Test Random Effect versus Fixed Effect Model}

The study undertake Hausman test in order to choose the most appropriate model between random effect model versus fixed effect model. The reason of doing this test is because our dataset used in this study is strong balanced panel data, therefore the possibilities of having cross sectional effects on companies or group of companies is something that cannot be ignored, and for this case pooled ordinary least square (OLS) model cannot be appropriate because OLS does not distinguish between various companies and deny heterogeneity/individuality that may exist. Therefore, Hausman test will help the study to choose the appropriate model for this study, the criterion of the selection will depend on the p-value. The following hypothesis will be applied for our econometric models (i.e., Model 1-ROA and Model 2-ROE).

Null hypothesis (Ho): Random effects model is appropriate.

Alternative hypothesis (H1): Random effects model is not appropriate.

The Hausman specification test for Model 1-ROA and Model 2-ROE are reported below on Table 4 and Table 5 respectively.

Table 4 (Model 1-ROA), the reported p values are $0.1488,0.3535$ and 0.3881 for model $1 \mathrm{a}$, model $1 \mathrm{~b}$ and model $1 \mathrm{c}$ respectively, The reported $\mathrm{p}$ values are not significant at 5\% significance level for all our three models (Model 1a, Model 1b and Model 1c), hence we did not rejected our null hypothesis and this mean that random effect model is accepted, and for this case the random effect model is appropriate and fit for the better estimation of our econometric models.

Table 4. The Hausman test results-Model 1 (ROA)

\begin{tabular}{|c|c|c|c|c|}
\hline \multicolumn{5}{|c|}{ Correlated Random Effects - Hausman Test } \\
\hline \multicolumn{5}{|c|}{ Equation: ROA } \\
\hline \multicolumn{5}{|c|}{ Test cross-section random effects } \\
\hline & Test Summary & Chi-Sq. Statistic & Chi-Sq. d.f. & Prob. \\
\hline Model 1a & Cross-section random & 3.810584 & 2 & 0.1488 \\
\hline Model 1b & Cross-section random & 2.079752 & 2 & 0.3535 \\
\hline Model 1c & Cross-section random & 1.893201 & 2 & 0.3881 \\
\hline
\end{tabular}

Source: E-VIEWS 8 analysis of data 
Table 5 (Model 2-ROE), the reported $\mathrm{p}$ values are $0.8744,0.0000$ and 0.0000 for model $2 \mathrm{a}$, model $2 \mathrm{~b}$ and model $2 \mathrm{c}$ respectively, The reported $\mathrm{p}$ value for model $2 \mathrm{a}$ is not significant at $5 \%$ significant level, hence we did not rejected our null hypothesis and this means that random effect model is accepted, and for this case the random effect model is appropriate and fit for the better estimation of our econometric model $2 \mathrm{a}$,but for model $2 \mathrm{~b}$ and model $2 \mathrm{c}$ the reported $\mathrm{p}$ values are significant at 5\% significance level, hence we rejected our null hypothesis and this mean that fixed effect model is accepted, and for this case the fixed effect model is appropriate and fit for the better estimation of our econometric models $2 \mathrm{~b}$ and $2 \mathrm{c}$.

Table 5. The Hausman test results-Model 2 (ROE)

\begin{tabular}{|c|c|c|c|c|}
\hline \multicolumn{5}{|c|}{ Correlated Random Effects - Hausman Test } \\
\hline \multicolumn{5}{|c|}{ Equation: ROE } \\
\hline \multicolumn{5}{|c|}{ Test cross-section random effects } \\
\hline & Test Summary & Chi-Sq. Statistic & Chi-Sq. d.f. & Prob. \\
\hline Model 2a & Cross-section random & 0.268368 & 2 & 0.8744 \\
\hline Model 2b & Cross-section random & 58.937790 & 2 & 0.0000 \\
\hline Model 2c & Cross-section random & 35.006373 & 2 & 0.0000 \\
\hline
\end{tabular}

Source: E-VIEWS 8 Analysis of Data

\subsubsection{Heteroskedasticity Test}

Heteroscedasticity arise when errors do not have constant variance, therefore the presence of heteroscedasticity in the dataset will lead to misleading results, and the values of t-test and F-test will be inaccurate when regression is run on the dataset having heteroscedasticity, Gujarati (2007). We use White test to check for presence of heteroscedasticity in our econometric models. The following hypothesis will be applied for all our econometric models (i.e., Model 1-ROA and Model 2-ROE).

Null hypothesis (Ho): Absence of heteroskedasticity

Alternative hypothesis (H1): Presence of heteroskedasticity

Table 6 (Model 1-ROA), the reported p values on Table 6 below are 0.0004, 0.3851 and 0.0042 for model $1 \mathrm{a}$, model $1 \mathrm{~b}$ and model $1 \mathrm{c}$ respectively, The reported $\mathrm{p}$ values are significant at 5\% significance level for our two models (Model 1a and Model 1c), hence we rejected our null hypothesis and accepted the alternative hypothesis which means that model 1a and model 1c are facing heteroskedasticity problem [i.e. Presence of heteroskedasticity in all three models] while the $\mathrm{p}$ value for model $1 \mathrm{~b}$ is not significant at $5 \%$ significance level, therefore we did not rejected our null hypothesis, which means that for model $1 \mathrm{~b}$, we accepted the null hypothesis that the model is not facing heteroskedasticity problem (i.e., Absence of heteroskedasticity in the model). 
Table 6. Heteroskedasticity test results-Model 1 (ROA)

\begin{tabular}{|c|c|c|c|}
\hline \multicolumn{4}{|c|}{ Heteroskedasticity Test: White } \\
\hline & Model 1a & Model 1b & Model 1c \\
\hline F-statistic & 4.879281 & 1.048853 & 3.583921 \\
\hline Prob. F(5,266) & 0.0003 & 0.3893 & 0.0037 \\
\hline Obs*R-squared & 22.85091 & 5.258878 & 17.16730 \\
\hline Prob.Chi-Square (5) & 0.0004 & 0.3851 & 0.0042 \\
\hline Scaled explained SS & 133.0465 & 41.37701 & 105.5455 \\
\hline Prob.Chi-Square (5) & 0.0000 & 0.0000 & 0.0000 \\
\hline
\end{tabular}

Source: E-VIEWS 8 analysis of data

Table 7 (Model 2-ROE), the reported $\mathrm{p}$ values on Table 7 below are $0.0000,0.6384$ and 0.2437 for model $2 \mathrm{a}$, model $2 \mathrm{~b}$ and model $2 \mathrm{c}$ respectively, The reported $\mathrm{p}$ values are not significant at 5\% significance level for our two models (Model 2b and Model 2c), therefore we did not rejected our null hypothesis, which means that for model $2 \mathrm{~b}$ and model $2 \mathrm{c}$, we accepted the null hypothesis that the models are not facing heteroskedasticity problem[i.e. Absence of heteroskedasticity in the models], while the $\mathrm{p}$ value for model $2 \mathrm{a}$ is significant at $5 \%$ significance level, hence we rejected our null hypothesis and accepted the alternative hypothesis which means that model $2 \mathrm{a}$ is facing heteroskedasticity problem (i.e., Presence of heteroskedasticity in the model).

Table 7. Heteroskedasticity test results-Model 2 (ROE)

\begin{tabular}{|l|l|l|l|}
\hline Heteroskedasticity Test: White & Model 2c \\
\hline & Model 2a & Model 2b & 1.334047 \\
\hline F-statistic & 8.530709 & 0.673700 & 0.2501 \\
\hline Prob. F(5,266) & 0.0000 & 0.6437 & 6.653838 \\
\hline Obs*R-squared & 37.58831 & 3.401408 & 0.2437 \\
\hline Prob.Chi-Square (5) & 0.0000 & 0.6384 & 534.5883 \\
\hline Scaled explained SS & 2690.718 & 272.6952 & 0.0000 \\
\hline Prob.Chi-Square (5) & 0.0000 & 0.0000 & \\
\hline
\end{tabular}

Source: E-VIEWS 8 analysis of data

\subsubsection{Test for Autocorrelations}

Autocorrelation (Serial correlation) arises when errors associated to a given time period carry over into future time periods. The autocorrelation test is needed to panel dataset because the presence of autocorrelation will affect our econometric model as a result the model will gives out misleading results. This study used the Breusch-Godfrey Serial correlation LM test to check for autocorrelation in the models and considered the following hypothesis below for all our two models (Model 1 and Model 2).

Null hypothesis (Ho): Absence of autocorrelations

Alternative hypothesis (H1): Presence of autocorrelations

Table 8 (Model 1-ROA), the reported p values on Table 8 below are $0.0000,0.0000$ and 0.0000 for model $1 \mathrm{a}$, model $1 \mathrm{~b}$ and model $1 \mathrm{c}$ respectively, The reported $\mathrm{p}$ values are 
significant at 5\% significance level for all our three models (Model 1a, Model 1b and Model 1c), hence we rejected our null hypothesis and accepted the alternative hypothesis which means that all our three models are facing autocorrelation problem (i.e., Presence of autocorrelation in all three models).

Table 8. Autocorrelation test results-Model 1 (ROA)

\begin{tabular}{|l|l|l|l|}
\hline Breusch-Godfrey Serial Correlation LM Test: \\
\hline & Model 1a & Model 1b & Model 1c \\
\hline F-statistic & 62.06558 & 51.39250 & 53.89909 \\
\hline Prob. F(2,267) & 0.0000 & 0.0000 & 0.0000 \\
\hline Obs*R-squared & 86.32315 & 75.60480 & 78.23171 \\
\hline Prob.Chi-Square (2) & 0.0000 & 0.0000 & 0.0000 \\
\hline
\end{tabular}

Source: E-VIEWS 8 analysis of data

Table 9 (Model 2-ROE), the reported p values on Table 9 below are 0.5205, 0.9279 and 0.6106 for model $2 \mathrm{a}$, model $2 \mathrm{~b}$ and model $2 \mathrm{c}$ respectively, The reported $\mathrm{p}$ values are not significant at 5\% significance level for all our three models (Model 2a, Model 2b and Model $2 \mathrm{c}$ ), hence we did rejected our null hypothesis, therefore we accepted the null hypothesis which means that all our three models are not facing autocorrelation problem (i.e., Absence of autocorrelation in all three models).

Table 9. Autocorrelation test results-Model 2 (ROE)

\begin{tabular}{|l|l|l|l|}
\hline Breusch-Godfrey Serial Correlation LM Test: \\
\hline & Model 2a & Model 2b & Model 2c \\
\hline F-statistic & 0.643973 & 0.073464 & 0.486056 \\
\hline Prob. F(2,267) & 0.5260 & 0.9292 & 0.6156 \\
\hline Obs*R-squared & 1.305766 & 0.149598 & 0.986724 \\
\hline Prob.Chi-Square (2) & 0.5205 & 0.9279 & 0.6106 \\
\hline
\end{tabular}

Source: E-VIEWS 8 analysis of data

\subsubsection{Panels Corrected Standard Errors (PCSEs) and Fixed Effect Regression Models}

Panel Corrected Standard Errors (PCSEs) model as an alternative to the Feasible Generalized Least Square (FGLS) for fitting the panel data models when the errors are not independent and identically distributed; rather the errors are either heteroskedastic across panels or heteroskedastic and contemporaneously correlated across panels, with or without autocorrelation (Kmeta, 1997; Hossain \& Hossain, 2015). Hence this study used PCSEs regression model for model $1(1 \mathrm{a}, 1 \mathrm{~b}$ and $1 \mathrm{c})$ and model $2 \mathrm{a}$, the reason for using this PCSEs model is due to the fact that the refereed econometric models have got heteroskedasticity and/or autocorrelation problems [reference to sections 4.2.4 and 4.2.5 respectively], hence this PCSEs model will correct it automatically and gives the reliable best estimates for all variables in the given models, while the study used fixed effect model for model $2 \mathrm{~b}$ and $2 \mathrm{c}$ because these models are free from heteroskedasticity and autocorrelation problems but also 
the Hausman test recommended for fixed effect model to be appropriate for the better estimation for model $2 \mathrm{~b}$ and model $2 \mathrm{c}$ (reference to sections 4.2.3, 4.2.4 and 4.2.5).

\subsection{Regression Analysis}

\subsubsection{Model 1-Return on Asset (ROA)}

Table 10. Panels Corrected Standard Errors (PCSEs) results-Model 1a

\begin{tabular}{|c|c|c|c|c|c|c|}
\hline \multicolumn{7}{|c|}{ Linear regression, correlated panels corrected standard errors (PCSEs) } \\
\hline Group variable: & Code & & Number of obs & & $=$ & 272 \\
\hline Time variable: & Year & & $\begin{array}{l}\text { Number of } \\
\text { groups }\end{array}$ & & $=$ & 34 \\
\hline Panels: & $\begin{array}{l}\text { Correlated } \\
\text { (balanced) }\end{array}$ & & obs per group: & $\min$ & $=$ & 8 \\
\hline Autocorrelation: & $\begin{array}{l}\text { No } \\
\text { autocorrelation }\end{array}$ & & & avg & $=$ & 8 \\
\hline & & & & $\max$ & $=$ & 8 \\
\hline Estimated covariances & $=$ & 595 & R-squared & & $=$ & 0.0962 \\
\hline $\begin{array}{l}\text { Estimated } \\
\text { autocorrelations }\end{array}$ & $=$ & 0 & Wald chi2(2) & & $=$ & 38.19 \\
\hline Estimated coefficients & $=$ & 3 & Prob $>$ chi 2 & & $=$ & 0.0000 \\
\hline & \multicolumn{6}{|l|}{ Panel-corrected } \\
\hline Roa & coef & Std. & err. & $\mathrm{Z}$ & $\mathrm{p}>|\mathrm{z}|$ & $\begin{array}{l}\text { [95\% Conf. } \\
\text { Interval] }\end{array}$ \\
\hline Stdr & -.1931806 & .0465002 & -4.15 & 0.000 & -.2843192 & -.1020419 \\
\hline $\mathrm{Siz}$ & .0100646 & .0024202 & 4.16 & 0.000 & .0053211 & .0148082 \\
\hline Cons & -.0720207 & .0563402 & -1.28 & 0.201 & -.1824455 & .0384041 \\
\hline
\end{tabular}

Source: STATA 10 analysis of data

Table 11. Panels Corrected Standard Errors (PCSEs) results-Model 1b

\begin{tabular}{|c|c|c|c|c|c|c|}
\hline \multicolumn{7}{|c|}{ Linear regression, correlated panels corrected standard errors (PCSEs) } \\
\hline Group variable: & Code & & Number of obs & & $=$ & 272 \\
\hline Time variable: & Year & & $\begin{array}{l}\text { Number of } \\
\text { groups }\end{array}$ & & $=$ & 34 \\
\hline Panels: & $\begin{array}{l}\text { Correlated } \\
\text { (balanced) }\end{array}$ & & Obs per group: & $\min$ & $=$ & 8 \\
\hline Autocorrelation: & $\begin{array}{l}\text { No } \\
\text { autocorrelation }\end{array}$ & & & avg & $=$ & 8 \\
\hline & & & & $\max$ & $=$ & 8 \\
\hline Estimated covariances & $=$ & 595 & R-squared & & $=$ & 0.1169 \\
\hline $\begin{array}{l}\text { Estimated } \\
\text { autocorrelations }\end{array}$ & $=$ & 0 & Wald chi2(2) & & $=$ & 35.58 \\
\hline Estimated coefficients & $=$ & 3 & Prob $>$ chi2 & & $=$ & 0.0000 \\
\hline & \multicolumn{6}{|l|}{ Panel-corrected } \\
\hline Roa & coef & Std. & err. & $\mathrm{z}$ & $\mathrm{p}>|\mathrm{z}|$ & $\begin{array}{l}\text { [95\% Conf. } \\
\text { Interval] }\end{array}$ \\
\hline ltdr & -.20093 & .0465122 & -4.32 & 0.000 & -.2920922 & -.1097679 \\
\hline Siz & .0092364 & .002693 & 3.43 & 0.001 & .0039582 & .0145147 \\
\hline cons & -.0667165 & .0614868 & -1.09 & 0.278 & -.1872283 & .0537954 \\
\hline
\end{tabular}

Source: STATA 10 analysis of data 
Table 12. Panels Corrected Standard Errors (PCSEs) results-Model 1c

\begin{tabular}{|c|c|c|c|c|c|c|}
\hline \multicolumn{7}{|c|}{ Linear regression, correlated panels corrected standard errors (PCSEs) } \\
\hline Group variable: & Code & & Number of obs & & $=$ & 272 \\
\hline Time variable: & Year & & $\begin{array}{l}\text { Number of } \\
\text { groups }\end{array}$ & & $=$ & 34 \\
\hline Panels: & $\begin{array}{l}\text { Correlated } \\
\text { (balanced) }\end{array}$ & & Obs per group: & $\min$ & $=$ & 8 \\
\hline \multirow[t]{2}{*}{ Autocorrelation: } & No autocorrelation & & & avg & $=$ & 8 \\
\hline & & & & $\max$ & $=$ & 8 \\
\hline $\begin{array}{l}\text { Estimated } \\
\text { covariances }\end{array}$ & $=$ & 595 & R-squared & & $=$ & 0.1564 \\
\hline $\begin{array}{l}\text { Estimated } \\
\text { autocorrelations }\end{array}$ & $=$ & 0 & Wald chi2(2) & & $=$ & 37.30 \\
\hline \multirow[t]{2}{*}{$\begin{array}{l}\text { Estimated } \\
\text { coefficients }\end{array}$} & $=$ & 3 & Prob $>$ chi2 & & $=$ & 0.0000 \\
\hline & \multicolumn{6}{|l|}{ Panel-corrected } \\
\hline Roa & coef & Std. & err. & $\mathrm{z}$ & $\mathrm{p}>|\mathrm{z}|$ & $\begin{array}{l}\text { [95\% Conf. } \\
\text { Interval] }\end{array}$ \\
\hline $\operatorname{tdr}$ & -.1571746 & .0339437 & -4.63 & 0.000 & -.223703 & -.0906462 \\
\hline $\mathrm{Siz}$ & .0079023 & .0028537 & 2.77 & 0.006 & .0023092 & .0134954 \\
\hline cons & .0013601 & .0693163 & 0.02 & 0.984 & -.1344974 & .1372175 \\
\hline
\end{tabular}

Source: STATA 10 analysis of data

\subsubsection{Model 2-Return on Equity (ROE)}

Table 13. Panels Corrected Standard Errors (PCSEs) results-Model 2a

\begin{tabular}{|c|c|c|c|c|c|c|}
\hline \multicolumn{7}{|c|}{ Linear regression, correlated panels corrected standard errors (PCSEs) } \\
\hline Group variable: & Code & & Number of obs & & $=$ & 272 \\
\hline Time variable: & Year & & Number of groups & & $=$ & 34 \\
\hline Panels: & $\begin{array}{l}\text { Correlated } \\
\text { (balanced) }\end{array}$ & & Obs per group: & $\min$ & $=$ & 8 \\
\hline \multirow[t]{2}{*}{ Autocorrelation: } & $\begin{array}{l}\text { No } \\
\text { autocorrelation }\end{array}$ & & & avg & $=$ & 8 \\
\hline & & & & $\max$ & $=$ & 8 \\
\hline Estimated covariances & $=$ & 595 & R-squared & & $=$ & 0.1169 \\
\hline $\begin{array}{l}\text { Estimated } \\
\text { autocorrelations }\end{array}$ & $=$ & 0 & Wald chi2(2) & & $=$ & 35.58 \\
\hline \multirow[t]{2}{*}{ Estimated coefficients } & $=$ & 3 & Prob $>$ chi 2 & & $=$ & 0.0000 \\
\hline & \multicolumn{6}{|l|}{ Panel-corrected } \\
\hline Roa & coef & Std. & err. & $\mathrm{z}$ & $\mathrm{p}>|\mathrm{z}|$ & $\begin{array}{l}\text { [95\% Conf. } \\
\text { Interval] }\end{array}$ \\
\hline stdr & 1.654026 & 1.53376 & 1.08 & 0.281 & -1.352089 & 4.660141 \\
\hline Siz & .1241438 & .105702 & 1.17 & 0.240 & -.0830283 & .3313159 \\
\hline cons & -3.064335 & 2.433583 & -1.26 & 0.208 & -7.834071 & 1.705401 \\
\hline
\end{tabular}

Source: STATA 10 Analysis of Data 
Table 14. Fixed Effect (FE) model results-Model 2b

\begin{tabular}{|c|c|c|c|c|c|c|}
\hline \multicolumn{3}{|c|}{ Fixed-effects (within) regression } & \multirow{2}{*}{$\begin{array}{l}\text { Number of obs } \\
\text { Number of groups }\end{array}$} & & \multirow{2}{*}{$\begin{array}{l}= \\
=\end{array}$} & \multirow{2}{*}{$\begin{array}{l}272 \\
34\end{array}$} \\
\hline Group variable: & & Code & & & & \\
\hline R-sq: & within $=$ & 0.2200 & Obs per group: & $\min$ & $=$ & 8 \\
\hline & between $=$ & 0.0216 & & avg & $=$ & 8.0 \\
\hline & overall $=$ & 0.0273 & & $\max$ & $=$ & 8 \\
\hline & & & $\mathrm{F}(2,236)$ & & $=$ & 33.27 \\
\hline corr(u_i, Xb) & $=$ & -0.8162 & Prob $>F$ & & $=$ & 0.0000 \\
\hline Roa & coef & Std. & err. & $\mathrm{Z}$ & $\mathrm{p}>|\mathrm{z}|$ & $\begin{array}{l}\text { [95\% Conf. } \\
\text { Interval] }\end{array}$ \\
\hline ltdr & -7.006298 & .868822 & -8.06 & 0.000 & $\begin{array}{l}-8.7179 \\
35\end{array}$ & -5.29466 \\
\hline Siz & .2153217 & .1642889 & 1.31 & 0.191 & $\begin{array}{l}-.10833 \\
84\end{array}$ & .5389817 \\
\hline _cons & -2.958252 & 3.658421 & -0.81 & 0.420 & $\begin{array}{l}-10.165 \\
59\end{array}$ & 4.249082 \\
\hline sigma_u & 1.5452722 & & & & & \\
\hline sigma_e & 1.4619806 & & & & & \\
\hline rho & .52767569 & (fraction of & ariance due to $\mathrm{u}$ i) & & & \\
\hline test that all $\mathrm{u} \_\mathrm{i}=$ & $0:$ & $\mathrm{F}(33,236)=$ & 2.96 & Prob $>F$ & $=$ & 0.0000 \\
\hline
\end{tabular}

Source: STATA 10 analysis of data

Table 15. Fixed Effect (FE) model results-Model 2c

\begin{tabular}{|c|c|c|c|c|c|c|}
\hline \multicolumn{3}{|c|}{ Fixed-effects (within) regression } & \multirow{2}{*}{$\begin{array}{l}\text { Number of obs } \\
\text { Number of groups }\end{array}$} & & \multirow{2}{*}{$\begin{array}{l}= \\
=\end{array}$} & \multirow{2}{*}{$\begin{array}{l}272 \\
34\end{array}$} \\
\hline Group variable: & & Code & & & & \\
\hline \multirow[t]{4}{*}{ R-sq: } & within $=$ & 0.1064 & obs per group: & $\min$ & $=$ & 8 \\
\hline & between= & 0.1144 & & avg & $=$ & 8.0 \\
\hline & overall $=$ & 0.0003 & & $\max$ & $=$ & 8 \\
\hline & & & $\mathrm{F}(2,236)$ & & $=$ & 14.05 \\
\hline $\operatorname{corr}(\mathrm{u}$ i, $\mathrm{Xb})$ & $=$ & -0.8472 & Prob $>F$ & & $=$ & 0.0000 \\
\hline Roa & coef & Std. & err. & $\mathrm{Z}$ & $\mathrm{p}>|\mathrm{z}|$ & $\begin{array}{l}\text { [95\% Conf. } \\
\text { Interval] }\end{array}$ \\
\hline $\operatorname{tdr}$ & -3.721946 & .719199 & -5.18 & 0.000 & $\begin{array}{l}-5.13881 \\
6\end{array}$ & -2.305076 \\
\hline $\mathrm{Siz}$ & .1833809 & .1758683 & 1.04 & 0.298 & $\begin{array}{l}-.163091 \\
5\end{array}$ & .5298532 \\
\hline _cons & -1.859236 & 3.93974 & -0.47 & 0.637 & $\begin{array}{l}-9.62078 \\
6\end{array}$ & 5.902315 \\
\hline sigma_u & 1.4508315 & & & & & \\
\hline sigma e & 1.5647643 & & & & & \\
\hline rho & .46227264 & (fraction of & ariance due to $\mathrm{u}$ i) & & & \\
\hline test that all $\mathrm{u}_{-} \mathrm{i}=$ & $0:$ & $\mathrm{F}(33,236)=$ & \begin{tabular}{l|l}
1.85 & $\mathrm{P}$ \\
\end{tabular} & $b>F$ & $=$ & 0.0048 \\
\hline
\end{tabular}

Source: STATA 10 analysis of data

\subsubsection{Discussion of Regression Results for Model 1 and Model 2}

Table 10, 11 and 12, presents the results of testing the relationship between corporate financial performance as measured by ROA and capital structure as measured by STDR, LTDR and TDR respectively. As shown on the Tables above (Table 10, Table 11 and Table 12), the results indicate a negative and statistically significant relationship between ROA and capital structure as measured by STDR, LTDR and TDR respectively at 5\% significance level. The coefficients of STDR, LTDR and TDR were $-0.1931806,-0.20093$ and -0.1571746 
respectively and the $\mathrm{p}$ values were $0.000,0.000$ and 0.000 respectively. The Tables above (Table 13, Table 14 and Table 15) also reported the prob $>$ chi2 of $0.0000,0.0000$ and 0.0000 for STDR (model 1a), LTDR (model 1b) and TDR (model 1c) respectively which indicate that the given models were found to be statistically significant at 5\% significance level. The results also indicate that the control variable as measured by size of the firm (SIZ) has a positive and statistically influence on corporate financial performance as measured by ROA with $\mathrm{p}$ values of $0.000,0.001$ and 0.006 respectively at $5 \%$ significance level.

Table 13, 14 and 15, presents the results of testing the relationship between corporate financial performance as measured by ROE and capital structure as measured by STDR, LTDR and TDR respectively. As shown on the Tables above (Table 13, Table 14 and Table $15)$, the results indicate a negative and statistically significant relationship between ROE and capital structure as measured by LTDR and TDR (Reference to Table 14 and Table 15) but a positive and statistically insignificant relationship between ROE and capital structure as measured by STDR (Reference to Table 13) all at 5\% significance level. The coefficients of STDR, LTDR and TDR were $+1.654026,-7.006298$ and -3.721946 respectively and the $p$ values were $0.281,0.000$ and 0.000 respectively. The Tables above (Table 13, Table 14 and Table 15) also reported the prob $>$ chi2 of $0.2951,0.0000$ and 0.0000 for STDR (model 2a), LTDR (model 2b) and TDR (model 2c) respectively which indicate that the STDR (model 2a) found to be statistically insignificant while LTDR (model 2b) and TDR (model 2c) models were found to be statistically significant at 5\% significance level. The results also indicate that the control variable as measured by size of the firm (SIZ) has no significant influence on corporate financial performance as measured by ROE with $p$ values of $0.240,0.191$ and 0.298 respectively at $5 \%$ significance level.

In Summary, the results shown on Tables (Table 10-15) indicate that capital structure, in general speaking has a negative and statistically significant influence on East African listed firm's financial performance at 5\% significance level, which suggest that an increase in capital structure (STDR,LTDR and TDR) will result to a decrease in corporate financial performance (ROA and ROE). These results show that in average profitable listed firms in East African prefers to use internal source of financing in their capital structure as compared to external source of financing (like Debts-STDR,LTDR and TDR), the possible reasons for this situation is due several reasons such as Information asymmetry problems and financial markets in the East African region are still developing, hence it's difficult for profitable firms to access the external sources of financing (Like Corporate bonds), therefore decided to depend much on internal sources of financing (Like Bank borrowings) (Mwambuli,2015).Furthermore this results are supporting pecking order theory and our results are consistent with the findings of previous studies such as Kaumbuthu (2011), Karadeniz et al. (2009), Zeitun \& Tian (2007), Rao et al. (2007), Huang \& Sang (2006), Goddard et al. (2005), Ngobo \& Capiez (2004), Eriotis et al. (2002), Fama \& French (2002), Gleason et al. (2000), Simerly \& Li (2000), Majumdar \& Chhibber (1999), Crnigol \& Mramor (2009), Klapper \& Tzioumis (2008), Dragota \& Smenescu (2008), Song (2005), Chen (2004), Bauer (2004), Hall et al. (2004), Deesomsak et al. (2004), Cassar \& Holmes (2003), Esperanca et al. (2003), Nivorozhkin (2002), Shyam-Sunder \& Myers (1999), Friend 
\& Lang (1988), Malanic et al. (2013), among others. Hence the study rejected the hypotheses $\mathrm{H} 1$ and $\mathrm{H} 2$.

\section{Conclusion and Recommendations}

\subsection{Conclusion}

This paper examines the influence which capital structure has had on corporate financial performance of listed non-financial companies in East African stock markets. There is no single study formulated in the East African region context that examines the influence of capital structure on corporate financial performance of listed non-financial firms, this study fill the gap in finance literatures by examining the influence of capital structure on corporate financial performance by considering East African region as a case study.

The study used panel data of 272 observations including 34 East African non-financial firms listed in East African stock markets such as Dar Es Salaam Stock Market (DSE), Nairobi Securities Exchange (NSE) and Uganda Securities Exchange (USE) for a period of 8 years (i.e., 2006-2013). The study used two econometric models with return on assets (ROA) and return on equity (ROE) as dependent variables, the reason of using these variables as a measure of corporate financial performance is due to the fact that East African Stock Markets as among of developing economies their capital markets are relatively under developed and are not active so accounting measures of financial performance are appropriate to measure firms performance as compared to market measures of financial performance and also to make our results significant and comparable with prior studies, because these accounting measures of financial performance were mostly employed in previous empirical studies, on the other hand the study used three independent variables such as short term debt ratio (STDR), long term debt ratio (LTDR) and total debt ratio (TDR) as a measure of capital structure and the reason behind this decomposition of total debt into short term and long term debts is due to the fact that the financial markets in the East African region is not well developed and many firms depends much on short term debts to finance their operations and growth as compared to long term debt (Reference to Table 1: Descriptive Statistics), hence we cannot ignore this decomposition of debts in order to examine its influence on corporate financial performance in East African region, furthermore the study used size of the firm (SIZ) as a control variable in order to control the differences in firm's operating environment, the reason behind this control variable is because prior literatures suggest that firm size is likely to influence its financial performance,

The study conducted preliminary tests before estimating our econometric model, we did for multicollinearity test as per Pearson correlation matrix and found that the panel data had no multicollinearity problem, then we checked for unit root test as per Levin-Lin-Chu (LLC) test and found all variables in our econometric model were stationary at both individual intercept and individual intercept and trend, and then we did the Hausman test and the results suggested for fixed effects model and at last we did for heteroskedasticity test (white test) and autocorrelation test (Breusch-Godfrey serial correlation LM test) and found that model 1a,model 1b,model 1c and model 2a with heteroscedasticity and /or autocorrelation problems, therefore the study used Panel Corrected Standard Errors (PCSEs) regression models so as to 
correct those problems on the panel dataset while model $2 \mathrm{~b}$ and model $2 \mathrm{c}$ were free from heteroscedasticity and /or autocorrelation problems then for these two models we employed fixed effect model.

Lastly, the result indicates that capital structure has a negative and statistically significant influence on East African listed firm's financial performance at 5\% significance level. These results show that in average profitable listed firms in East African prefers to use internal source of financing in their capital structure as compared to external source of financing (like Debts-STDR, LTDR and TDR), the possible reasons for this situation is due several reasons such as Information asymmetry problems and financial markets in the East African region are still developing, hence it's difficult for profitable firms to access the external sources of financing (Like Corporate bonds), therefore decided to depend much on internal sources of financing (Like Bank borrowings) (Mwambuli, 2015). Furthermore these results are supporting pecking order theory

\subsection{Recommendations}

\subsubsection{Corporate Financial Managers}

The study recommends that, corporate financial managers of East African non-financial listed firms should reduce financing their operations and growth by debt (STDR, LTDR and TDR) on their capital structure in order to enhance their corporate financial performance, since a negative and statistically significant relationship exist between capital structure and corporate financial performance, furthermore this study recommends the East African non-financial listed firms to finance their operations and growth with internal sources of financing (like retained earnings) and used external sources of financing (like debts) as a last option after full utilization of internal sources of financing as supported by pecking order theory.

\subsubsection{Regulatory Authorities}

The results of this study have significant policy implications to Securities markets regulatory authorities in East African region such as East African member states securities regulatory authority (EASRA) and their respective countries securities markets regulatory authorities such as capital markets and securities authority (CMSA) in Tanzania, capital market authority (CMA) in Kenya, capital market authority (CMA) in Uganda and capital market authority (CMA) in Rwanda, to formulate policies relating to securities markets in general, like improving of financial markets in the region etc. Our study shown that, East African firms are using more debts in their capital structure to finance their operations and growth (Reference to Table 1: Descriptive Statistics), hence these securities regulatory authorities should regulate the debt market in the region in order to reduce the cost of debt.

\subsubsection{Future Research}

The future research can be extended after considering the limitations of our study. A future studies could be extended after considering the following points (1) The further study could examine the influence (if any) of capital structure on sector wise (as per industry-like Manufacturing firms) for East African non-financial listed firms (2) To include more control 
variables which are likely to influence financial performance such as macroeconomic variables (like gross domestic product - GDP) (3) Furthermore, the future research could consider other capital structure theories like, market timing theory, agency theory etc.

\section{References}

Abu-Rub, N. (2012). Capital structure and firm performance: Evidence from Palestine stock exchange. Journal of Money, Investment and Banking, 23, 109-117.

Alam, N., Rahaman, A., Mainul Ahsan, A. F. M., \& Hasan, B. (2014). Influence of capital structure on firm performance: Evidence from Bangladesh. International Journal of Business and Management, 9(5), 184-194.

Bauer, P. (2004). Determinants of capital structure: Empirical evidence from the Czech Republic. Czech Journal of Economics and Finance, 54, 2-21.

Baum, C. F., Schafer, D., \& Talavera, O. (2007). The effects of short-term liabilities on profitability: The case of Germany. Money Macro and Finance (MMF) Research Group Conference 2006 61, Money Macro and Finance Research Group.

Bevan, A., \& Danbolt, J. (2002). Capital structure and its determinants in the United Kingdom-A decomposition analysis. Applied Financial Economics, 20(3), 159-170. http://dx.doi.org/10.1080/09603100110090073

Cassar, G., \& Holmes, S. (2003). Capital structure and financing of SMEs: Australian $\begin{array}{llll}\text { evidence. Accounting and } & \text { Finance, }\end{array}$ http://dx.doi.org/10.1111/1467-629X.t01-1-00085

Champion. (1999). Finance: the joy of leverage. Havard Business Review, 77, 19-22.

Chang, F., Wang, Y., Lee, R. N., \& Thu La, D. (2014). Capital structure decisions and firm performance of Vietnamese SOES. Asian Economic and Financial Review of Finance, 4(11), $1545-1563$.

Chen, J. (2004). Determinants of capital structure of Chinese-listed firms. Journal of Business Research, 57(12), 1341-1351. http://dx.doi.org/10.1016/S0148-2963(03)00070-5

Črnigoj, M., \& Mramor, D. (2009). Determinants of capital structure in emerging European economies: Evidence from Slovenian firms. Emerging Markets Finance and Trade, 45(1), 72-89. http://dx.doi.org/10.2753/REE1540-496X450105

Deesomsak, R., Paudyal, K., \& Pescetto, G. (2004). The Determinants of capital structure: Evidence from Asia Pacific Region. Journal of Multinational Financial Management, 14, 387-405. http://dx.doi.org/10.1016/j.mulfin.2004.03.001

Dewaelheyns, N., \& Van Hulle, C. (2012). Capital structure adjustments in private business group companies. Applied Financial Economics, 1275-1288. http://dx.doi.org/10.1080/09603107.2012.654912

Donaldson, G. (1961). Corporate debt capacity: Boston, A study of Corporate debt policy and 
the determination of corporate date capacity. Division of Research, Graduate School of Business Administration, Harvard University.

Dragota, I., \& Semenescu, A. (2008). A Dynamic analysis of capital structure determinants empirical results for Romanian capital market. Empirical Results for Romanian Capital Market, 4, 65-80.

Ebaid, I. E. (2009). The impact of capital - structure choice on firm performance: Empirical evidence from Egypt. The Journal of Risk Finance, 10(5), 477-487. http://dx.doi.org/10.1108/15265940911001385

Eriotis, N. P., Franguoli, Z., \& Neokosmides, Z. V. (2002). Profit margin and capital structure: An empirical relationship. Journal of Applied Business Research, 18(2), 85-89.

Esperanca, J. P., Gama, A., \& Gulamhussen, M. (2003). Corporate debt policy of small firms: An empirical (Re) Examination. Journal of Small Business and Enterprise Development, 10, 62-80. http://dx.doi.org/10.1108/14626000310461213

Fama, E., \& French, K. (2002). Testing tradeoff and pecking order predictions about dividends and debt. Review of Financial Studies, 15, 1-33. http://dx.doi.org/10.1093/rfs/15.1.1

Focardi, S., \& Fabozzi, F. (2004). The mathematics of financial modelling and investment management. Hoboken: John Wiley and Sons.

Frank, M., \& Goyal, V. (2003). Testing the pecking order theory of capital structure. Journal of Financial Economics, 67, 217-248. http://dx.doi.org/10.1016/S0304-405X(02)00252-0

Friend, I., \& Lang, L. (1988). An empirical test of the impact of managerial self-interest on corporate capital structure. Journal of Finance, 43, 271-281. http://dx.doi.org/10.1111/j.1540-6261.1988.tb03938.x

Ghosh, C., Nag, R., \& Sirmans, C. (2000). The pricing of seasoned equity offerings: Evidence from REITs. Real Estate Economics, 28, 368-384. http://dx.doi.org/10.1111/1540-6229.00805

Givoly, D., Hayn, C., Ofer, A., \& Sarig, S. (1992). Taxes and capital structure: Evidence from firm's response to The Tax Reform Act of 1986. Review of Financial Studies, 5, 331-355. http://dx.doi.org/10.1093/rfs/5.2.331

Gleason, K., Mathur, L., \& Mathur, I. (2000). The interrelationship between culture, capital structure and performance: Evidence from European retailers. Journal of Business Research, 50, 185-191. http://dx.doi.org/10.1016/S0148-2963(99)00031-4

Goddard, J., Tavakoli, M., \& Wilson, J. (2005). Determinants of profitability in European manufacturing and services: Evidence from a dynamic panel data. Applied Financial Economics, 15, 1269-1282. http://dx.doi.org/10.1080/09603100500387139

Gujarati, D. N. (2007). Basic Econometrics. India: Tata McGraw-Hill Edition. 
Hadlock, C., \& James, C. (2002). Do banks provide financial slack. Journal of Finance, 57, 1383-1420. http://dx.doi.org/10.1111/1540-6261.00464

Hall, G., Hutchinson, P., \& Michaelas, N. (2004). Determinants of the capital structures of European SMEs. Journal of Business Finance and Accounting, 31, 711-728. http://dx.doi.org/10.1111/j.0306-686X.2004.00554.x

Holz, C. A. (2002). The impact of liability-asset ratio on profitability in China's industrial state-owned enterprises. China Economic Review, 13, 1-26. http://dx.doi.org/10.1016/S1043-951X(01)00054-2

Hossain, I., \& Hossain, A. (2015). Determinants of capital structure and testing of theories: A study on the listed manufacturing companies in Bangladesh. International Journal of Economics and Finance, 7(4), 176-190. http://dx.doi.org/10.5539/ijef.v7n4p176

Huang, G., \& Song, F. (2006). The determinants of capital structure: Evidence from China. China Economic Review, 17, 14-36. http://dx.doi.org/10.1016/j.chieco.2005.02.007

Igbinosa, O., \& Chijuka, M. (2014). Determinants of capital structure of listed firms in Nigeria. European Journal of Accounting, Auditing and Finance Research, 2(10), 96-111.

Jermias, J. (2008). The relative influence of competitive intensity and business strategy on the relationship between financial leverage and performance. British Accounting Review, 40, 71-86. http://dx.doi.org/10.1016/j.bar.2007.11.001

Kant, E. (2014). The determinants of capital structure: An empirical study on Dutch firms. 4th IBA Bachelor Thesis Conference, University of Twente, Netherlands.

Karadeniz, E., Kaandir, S. Y., Balcilar, M., \& Onal, Y. B. (2009). Determinants of capital structure": Evidence from Turkish lodging companies. International Journal of Contemporary Hospitality Management, $\quad$ 21(5), 594-609. http://dx.doi.org/10.1108/09596110910967827

Kaumbuthu, A. J. (2011). The relationship between capital structure and financial performance: A study of firms listed under industrial and allied sector at the NSE", MBA Dissertation, University of Nairobi. [Online] Available: http://erepository.uonbi.ac.ke

Khan, M, Shah, M. S., Haq, F., \& Shah, S. Z. (2014). Determinants of capital structure in non-financial companies of Pakistan. Journal of Poverty, Investment and Development, 6, 20-28.

Klapper, L., \& Tzioumis, K. (2008). Taxation and capital structure: evidence from a Transition economy. London: The Hellenic Observatory. http://dx.doi.org/10.1596/1813-9450-4753

Kmeta, J. (1997). Elements of Econometrics (2nd ed.). Ann Arbor: University of Michigan Press. http://dx.doi.org/10.3998/mpub.15701

Kraus, A., \& Litzenberger, R. (1973). A state preference model of optimal financial leverage. The Journal of Finance, 28, 911-921. http://dx.doi.org/10.1111/j.1540-6261.1973.tb01415.x 
Levin, A., Lin, C. F., \& Chu, C. S. J. (2002). Unit root test in panel data: Asymptotic and finite-sample properties. Journal of Econometrics, 108, 1-24.

Lewis-Beck, M. S. (1993). Applied Regression: An introduction to regression analysis. Singapore: Sara Miller McCune, Sage publications Inc.

Majumdar, S., \& Chhibber, P. (1999). Capital structure and performance: evidence from a transition economy on an aspect of corporate governance. Public Choice, 98, 287-305. http://dx.doi.org/10.1023/A:1018355127454

Malanic, D., Dencic-Mihajlov, K., \& LLjubenovic, E. (2013). The determinants of capital structure in emerging capital markets: Evidence from Serbia. European Research Studies $X V I(2), 98-119$.

Margaritis, D., \& Psillaki, M. (2010). Capital structure, equity ownership and firm performance. Journal of Banking \& Finance, 34(3), 621-632. http://dx.doi.org/10.1016/j.jbankfin.2009.08.023.

Michaelas, N., Chittenden, F., \& Poutziouris, P. (1999). Financial policy and capital structure choices in UK SMEs: Empirical evidence from company panel data. Small Business Economics, 12, 113-130. http://dx.doi.org/10.1023/A:1008010724051

Miller, M., \& Modigliani, F. (1961). Dividend policy, growth and valuation of shares. The Journal of Business, 34(4), 411-433. http://dx.doi.org/10.1086/294442

Modigliani, F., \& Miller, M. (1958). The cost of capital, corporation finance and the theory of investment. American Economic Review, 48, 261-275.

Modigliani, F., \& Miller, M. (1963). Corporate income taxes and the cost of capital. American Economic Review, 53, 433-443.

Mwambuli, E. L. (2015). What determine corporate capital structure in developing economies? Evidence from East African stock markets. Research Journal of Finance and Accounting, 6(12), 221-239.

Mwangi, L., Makau, M., \& Kosimbei, G. (2014). Relationship between capital structure and performance of non-financial companies listed in Nairobi securities exchange, Kenya. Global Journal of Contemporary Research in Accounting, Auditing and Business Ethics (GJCRA), 1(2), 72-90.

Myers, S. C. (1984). The capital structure puzzle. Journal of Finance, 39(3), 575-592. http://dx.doi.org/10.2307/2327916

Myers, S. C. (2003). Financing of corporations. Handbook of Economics of Finance, 1, 215-253. http://dx.doi.org/10.1016/S1574-0102(03)01008-2

Myers, S. C., \& Majluf, N. S. (1984). Corporate financing and investment decisions when firms have information that investors do not have. Journal of Financial Economics, 13(2), 187-221. http://dx.doi.org/10.1016/0304-405X(84)90023-0 
Ngobo, P. V., \& Capiez, A. (2004). Structure du capital et performance de l'entreprise: le role modérateur des différences culturelles. Congrès de l'Association Internationale de Management Stratégique (AIMS). Le Havre.

Nirajini, A., \& Priya, K. B. (2013). Impact of capital structure decisions on firm performance of the listed trading companies in Sri Lanka. International Journal of Scientific and Research Publications, 3(5), 1-9.

Nivorozhkin, E. (2002). Capital structures in emerging stock markets: The case of Hungary. The Developing Economies, 40(2), 166-187. http://dx.doi.org/10.1111/j.1746-1049.2002.tb01006.x

Oke, M., \& Obalade, A. (2015). Test the validity of optimal capital structure theory in Nigeria listed oil firms. The International Journal of Economics, Commerce and Management, III, 1-15.

Onaolapo, A. A., \& Kajola, S. O. (2010). Capital structure and firm performance-Evidence from Nigeria. The International European Journal of Economics, Finance and Administrative Sciences, 25, 70-82.

Petersen, M., \& Rajan, R. (1994). The benefits of lending relationships: Evidence from small business data. Journal of Finance, 49, 1367-1400. http://dx.doi.org/10.1111/j.1540-6261.1994.tb04418.x

Phillips, P., \& Sipahioglu, M. (2004). Performance implications of capital structure: Evidence from quoted UK organizations with hotel interests. The Service Industries Journal, 24(5), 31-51. http://dx.doi.org/10.1080/0264206042000276829

Pouraghajan, A., Malekian, E., Emamgholipour, M., Lotfollapour, V., \& Bagheri, M. M. (2012). The relationship between capital structure and firm performance evaluation measures: Evidence from the Tehran stock exchange. International Journal of Business and Commerce, 1(9), 166-181.

Ramaswamy, K. (2001). Organization ownership, competitive intensity and firm performance: An empirical study of the Indian manufacturing sectors. Strategic Management Journal, 22, 989-998. http://dx.doi.org/10.1002/smj.204

Rao, N. V., Al-Yahyee, K., \& Syed, L. (2007). Capital Structure and financial performance: Evidence from Oman. Indian Journal of Economics and business, 7, 1-14.

Roden, D., \& Lewellen, W. (1995). Corporate capital structure decisions: Evidence from leverage buyouts. Financial Management, 24, 76-87. http://dx.doi.org/10.2307/3665536

San, O. T., \& Heng, T. B. (2011). Capital structure and corporate performance of Malaysian construction sector. International Journal of Humanities and Social Science, 22, 989-998.

Shyam-Sunder, L., \& Myers, S. C. (1999). Testing static trade-off against pecking order models of capital structure. Journal of Financial Economics, 51, 219-244. http://dx.doi.org/10.1016/S0304-405X(98)00051-8 
Simerly, R., \& Li, M. (2000). Environmental dynamism, financial leverage and performance: A theoretical integration and an empirical test. Strategic Management Journal, 24, 76-87.

Smith, D. J., Chen, J. G., \& Anderson, H. D (2012). The relationship between capital Structure and product markets: Evidence from New Zealand. Review of Quantitative Finance and Accounting, 38(1), 1-24. http://dx.doi.org/10.1007/s11156-010-0216-x

Song, H. S. (2005). Capital structure determinants: An empirical study of Swedish companies. No 25, Working Paper Series, CESIS-Centre of Excellence for Science. [Online] Available: http://www.diva-portal.org/smash/get/diva2:565199/FULLTEXT01.pdf

Soumadi, M. M., \& Hayajneh, S. O. (2012). Capital Structure and corporate performance: Empirical study on the public Jordanian shareholdings firms listed in the Amman stock market. Journal European Scientific Journal, 8(22), 173-189.

Vinasithamby, S. (2014). Determinants of capital structure-A study of listed banks finance and insurance companies in Colombo stock exchange in Sri Lanka. International Journal of Economics, Commerce and Management, 11, 1-18.

Zeitun, R., \& Tian, G. G. (2007). Capital structure and corporate performance: Evidence from Jordan. The Australasian Accounting Business and Finance Journal, 1(4), 40-61.

\section{Copyright Disclaimer}

Copyright for this article is retained by the author(s), with first publication rights granted to the journal.

This is an open-access article distributed under the terms and conditions of the Creative Commons Attribution license (http://creativecommons.org/licenses/by/3.0/). 